\title{
ROTAVIRUS AND REOVIRUS STABILITY IN MICROORGANISM-FREE DISTILLED AND WASTEWATERS
}

\author{
Audrey E. McDaniels ${ }^{1 *}$, Kenneth W. Cochran ${ }^{2}$, John J. Gannon ${ }^{1 *}$ \\ and GeOrGE W. Williams ${ }^{3} \dagger$ \\ ${ }^{1}$ Departments of Environmental and Industrial Health, ${ }^{2}$ Epidemiology and ${ }^{3}$ Biostatistics, School of \\ Public Health, The University of Michigan, Ann Arbor, MI 48109, U.S.A.
}

(Received November 1982)

\begin{abstract}
Survival of calf rotavirus and reovirus under controlled laboratory conditions in microorganism-free, distilled and wastewater at 8 and $26^{\circ} \mathrm{C}$ was examined by periodic measurement of cytopathic effects (CPE) and indirect fluorescent antibody (IFA) assays. Five samples of both water-types were collected and inoculated with the two viruses. Three samples of each type of water were divided into two bottles, one per virus, for incubation at $8^{\circ} \mathrm{C}$. Two samples were used at $26^{\circ} \mathrm{C}$, one per trial. In the absence of light and shaking at $26^{\circ} \mathrm{C}, 7-13$ days were required for a loss of $90 \%$ infectivity for rotavirus and reovirus, while at $8^{\circ} \mathrm{C}$, averages were 80 days for rotavirus and 260 days for reovirus. Virus infectivity remained for more than 30 days at $26^{\circ} \mathrm{C}$ and 400 days at $8^{\circ} \mathrm{C}$. Rates of decline were $10-100$ times greater at 26 than at $8^{\circ} \mathrm{C}$, but at both temperatures, the MPN $\log _{10}$ rate of decline of infectivity was linear.
\end{abstract}

Key words-survival, rotavirus, wastewater, stability, reovirus, distilled water

\section{INTRODUCTION}

Little is known of the environmental survival properties of a newly discovered agent of diarrhea, rotavirus, a member of the Reoviridae family, found to exist throughout the world (Steinhoff, 1980). To learn more about its prevalence, we have studied the survival of rotavirus in distilled and in wastewater.

Wastewater treatment plants have been shown to release effluents containing viable viruses into bodies of water (WHO Technical Report, 1979). Polio-, coxsackie-, echo- and reoviruses are commonly isolated from polluted bodies of water (Sekla et al., 1980) and have been recovered long distances from their sources (Dahling \& Sáfferman, 1979). When this study was begun, rotavirus, the leading cause of infant winter diarrhea, had not been identified in wastewater. Information received through personal communication has indicated the presence of rotavirus in contaminated drinking water and wastewater in Texas and South America (Gerba, 1980). Because it is released in large quantity, one billion per gram of feces (Melnick \& Rennick, 1980) from infants during illness and in more moderate numbers from adults, rotavirus would be expected to occur in wastewater. Since all rotaviruses

*Present address: Environmental Monitoring and Support Laboratory, United States Environmental Protection Agency, Cincinnati, OH 45268, U.S.A.

$\dagger$ Present address: Department of Biostatistics, Cleveland Clinic Foundation, Cleveland, OH 44106, U.S.A.

Address all correspondence to: Professor John J. Gannon. Department of Environmental and Industrial Health, The University of Michigan, Ann Arbor, MI 48109, U.S.A. have been found structurally identical and antigenically related (Wyatt et al., 1978) and in the absence of dependable methods for growing human rotavirus in vitro, calf rotavirus was used as its surrogate. Reovirus has frequently been isolated from wastewater and its survival properties previously studied (Mahnel et al., 1977). In the present study, reovirus was treated under the same conditions as rotavirus and comparisons made.

\section{MATERIALS AND METHODS}

\section{Viruses and viral assay}

Calf rotavirus (Cody isolate, obtained from Dr C. A. Mebus, University of Nebraska, NE) was grown in primary bovine embryonic kidney cells (BEK) which were prepared according to the method of Schmidt (1979). The growth medium was minimum essential medium Eagles' with Earl's salts and L-glutamine (EMEM) containing $10 \%$ fetal, newborn or calf serum; penicillin (100 units $\left.\mathrm{ml}^{-1}\right)$; streptomycin $\left(100 \mu \mathrm{g} \mathrm{ml}^{-1}\right)$; amphotericin $\mathrm{B}\left(2 \mu \mathrm{g} \mathrm{ml}^{-1}\right)$; and sodium bicarbonate $\left(1.5 \mathrm{gl}^{-1}\right)$. The same medium without serum was used for propagation of stock virus and completion of assays for which amphotericin B was omitted and $25 \mathrm{mM}$ HEPES included. Rotavirus assays were done in secondary BEK cells, grown in flatbottom, 96-well microtiter plates, examined daily for 5 days to detect cytopathic effects (CPE); while for indirect fluorescent antibody (IFA), the method of Riggs (1979) was followed except that $12-\mathrm{mm}$ round glass coverslips in one-dram shell vials were used. Detection was enhanced by centrifuging newly inoculated vials as recommended by Bryden et al. (1976) with the modification of $30 \mathrm{~min}$ of centrifuging at $200 \mathrm{~g}$. Coverslips were examined at $24 \mathrm{~h}$. Reovirus type 3 (Abney strain, from Dr H. Hatch CDC, Atlanta, GA) was grown and assayed by similar methods in L 929 cells (from Dr H. F. Maassab, the University of Michigan, MI) but fetal calf serum was 
reduced to $5 \%$ and no amphotericin B or HEPES were used. Rota- and reovirus pools from 20 and 10 bottles respectively, of $32 \mathrm{oz}$. volume were rapidly frozen and thawed 3 times and centrifuged at $200 \mathrm{~g}$ for $15 \mathrm{~min}$ to remove cellular debri. The supernatants were purified by centrifuging at $100,000 \mathrm{~g}$ for $3 \mathrm{~h}$, and the pellets resuspended in approx. $5 \mathrm{ml}$ of sterile distilled water and filtered through $0.45 \mu \mathrm{m}$, Duo-Fine filter paper (Filterite Co., Timmonium, MD). Hyperimmune rota- and reovirus antisera were prepared in rabbits (Kapikian et al., 1979).

Virus concentrations were estimated quantitatively using the most probable number (MPN) method (Chang et al., 1965). These end-points were calculated by the method of Rowe et al. (1977) and results expressed as $\log _{10}$ MPN $(1.0 \mathrm{ml})$, plotted against time. The time of loss of $90 \%$ of the virus population $\left(T_{90}\right)$ was also calculated. The decline in virus titers was examined graphically by regression curves. Both $r^{2}$ (Ostle, 1954) and F-statistic (Draper \& Smith, 1966) indicated that declines most closely followed linear regression curves at 8 and $26^{\circ} \mathrm{C}$. Correlation coefficients of initial titers and their rates of loss were significantly positive. Therefore, to prevent this correlation from affecting the significance of the other variables (of virus, medium, assay and trial) all initial titers at $26^{\circ} \mathrm{C}$ were adjusted to the average common titer. Each of the variables in the experimental design was then examined for its significance on the adjusted rates of decline at $26^{\circ} \mathrm{C}$ and the averaged rates at $8^{\circ} \mathrm{C}$ by analysis of variance, using a $2^{3}$ factorial design in the BMD8V analysis of variance computer program for balanced designs (Dixon, 1977). The $95 \%$ confidence intervals of the means are included in figures and were determined by the Working-Hotelling approach (Neter \& Wasserman, 1974).

\section{Test waters}

Virus survival was measured in sterile distilled water and in samples of raw domestic wastewater obtained from the Ann Arbor, secondary activated treatment plant. Autoclaving is known to alter the characteristics of proteins, fats and carbohydrates. Therefore, in order to minimize the damage to any substances present during the removal of microorganisms, the 5 wastewater samples collected at various seasons, were treated using a combination of pas-

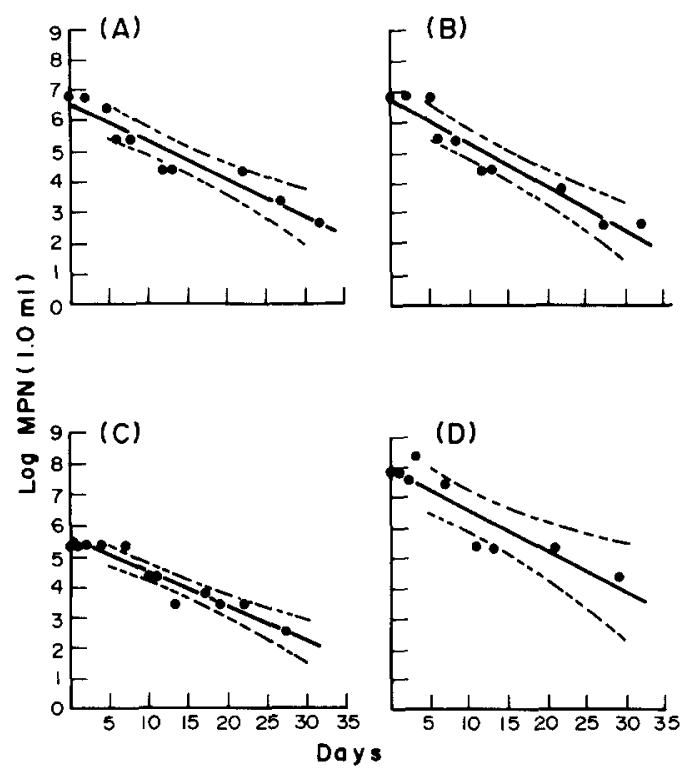

Fig. 1. Loss of infectivity as measured by CPE of observed data at $26^{\circ} \mathrm{C}$ with linear regression predictions and $95 \%$ confidence intervals for means. (A) Rotavirus-distilled water; (B) rotavirus-wastewater; (C) reovirus-distilled water; (D) reovirus-wastewater.

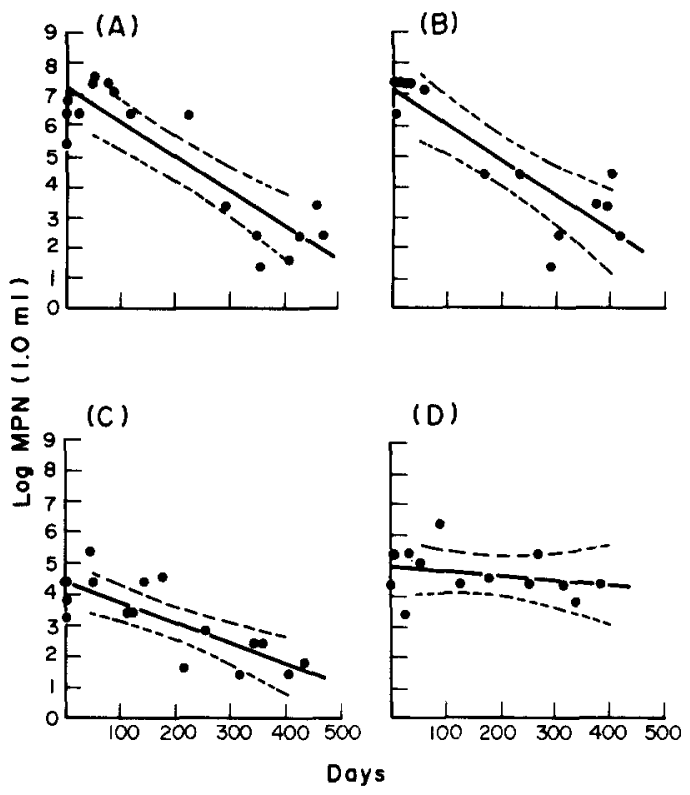

Fig. 2. Loss of infectivity as measured by CPE of observed data at $8^{\circ} \mathrm{C}$ with linear regression predictions and $95 \%$ confidence intervals for means. (A) Rotavirus-distilled water; (B) rotavirus-wastewater; (C) reovirus-distilled water; (D) reovirus-wastewater.

teurization $\left(62^{\circ} \mathrm{C}, 20 \mathrm{~min}\right)$, freezing, thawing and antibiotics of penicillin (500 units $\left.\mathrm{ml}^{-1}\right)$; streptomycin $\left(500 \mu \mathrm{g} \mathrm{ml}^{-1}\right)$; amphotericin B $\left(5 \mu \mathrm{g} \mathrm{ml}^{-1}\right)$.

\section{Procedure for measuring survival}

For virus-water mixtures incubated in a refrigerator adjusted to maintain $8^{\circ} \mathrm{C}$, three samples of microorganismfree distilled water and three of wastewater were collected. Each was distributed into two sterile $100 \mathrm{ml}$ flint glass bottles, loosely capped and covered with aluminum foil to prevent entrance of light. One set was inoculated with filtered virus pellet suspensions of rotavirus and one with reovirus for measurement of titers. For those samples incubated in a refrigerator adjusted to $26^{\circ} \mathrm{C}, 300 \mathrm{ml}$ of each water type from another sample collection, was inoculated rotavirus and $300 \mathrm{ml}$ with reovirus. After thorough mixing. replicates of 3 for each of the water-virus mixtures were distributed into previously described bottles and titers measured. This procedure was repeated twice for samples incubated at $26^{\circ} \mathrm{C}$. Initial titers ranged from $1 \times 10^{6}$ to $1 \times 10^{8} \log _{10}$ MPN $(1.0 \mathrm{ml})$. At specified intervals during storage under static conditions after shaking by hand vigorously $10 \mathrm{~s}, 1 \mathrm{ml}$ aliquots were removed and a final concentration of $1 \mu \mathrm{m} \mathrm{ml}^{-1}$ of Difco 1:250 trypsin (Clark et al., 1979) added; aliquots were incubated for $30 \mathrm{~min}$ at room temperature before performing ten-fold serial dilutions in serum free EMEM. Four replicate inoculations of $0.1 \mathrm{ml}$ from each virus dilution were added to cell monolayers in microtiter plates and to cell covered coverslips in one-dram shell vials, followed by addition of $0.2 \mathrm{ml}$ of virus-cell maintenance medium. All assays were performed immediately after sample preparation and at the intervals indicated in Figs 1 and 2.

These materials and methods are described in greater detail elsewhere (McDaniels, 1981).

\section{RESULTS}

\section{Stability of rota- and reoviruses}

Typical patterns of inactivation of rota- and reoviruses are shown in Figs 1 and 2 which present the 
Table 1. Initial rotavirus titers in $\log _{10} \mathrm{MPN}(1.0 \mathrm{ml})$ and their rates of decline at $26^{\circ} \mathrm{C}^{*}$

\begin{tabular}{cccc}
\hline & IFA & \multicolumn{3}{c}{ CPE } \\
Y-intercept & Slope & Y-intercept & Slope \\
\hline \multicolumn{4}{c}{ Distilled water } \\
6.05 & -0.0707 & 6.55 & -0.1210 \\
6.05 & -0.0900 & 6.59 & -0.1235 \\
6.10 & -0.0589 & 6.69 & -0.1300 \\
6.36 & -0.0985 & 6.93 & -0.1403 \\
6.66 & -0.1148 & 6.96 & -0.1552 \\
6.78 & -0.1261 & 7.03 & -0.1594 \\
& \multicolumn{4}{c}{ Wastewater } \\
6.50 & -0.0973 & 6.61 & -0.1392 \\
6.75 & -0.1472 & 6.69 & -0.1407 \\
6.77 & -0.1482 & 6.69 & -0.1422 \\
6.78 & -0.1482 & 8.17 & -0.2217 \\
6.87 & -0.1161 & 8.28 & -0.2167 \\
6.93 & -0.1167 & 8.37 & -0.2123 \\
\hline
\end{tabular}

*Correlation coefficients significant at a probability level of 0.05 . Groups for each slope showed $F$-statistic significances equal to or less than 0.05 for linear regression. $r^{2} \mathrm{~s}$ were greater than 0.80 indicating the closest relationship to linear regression.

observed loss of infectivity at 26 and $8^{\circ} \mathrm{C}$ as measured by cytopathology. Inactivation was log-linear over considerable ranges of virus-titer and of time, differing only in rate of decline for differing viruses (rotaor reo-), temperatures $\left(8\right.$ or $26^{\circ} \mathrm{C}$ ), assay (CPE or IFA) or medium (distilled or wastewater). Examination of the data showed a significant correlation between initial titers and rates of decline, especially at $26^{\circ} \mathrm{C}$ (Table 1; Fig 3), and therefore, rates were adjusted to reflect a uniform average initial titer. These results may be presented most succinctly by listing the calculated average times $\left(T_{90}\right)$ for $90 \%$ or $1-\log$ losses in viral concentration, as shown in Table 2.

\section{Water characterization}

Influent wastewater $24 \mathrm{~h}$ composite analyses performed by the Ann Arbor treatment plant on days of

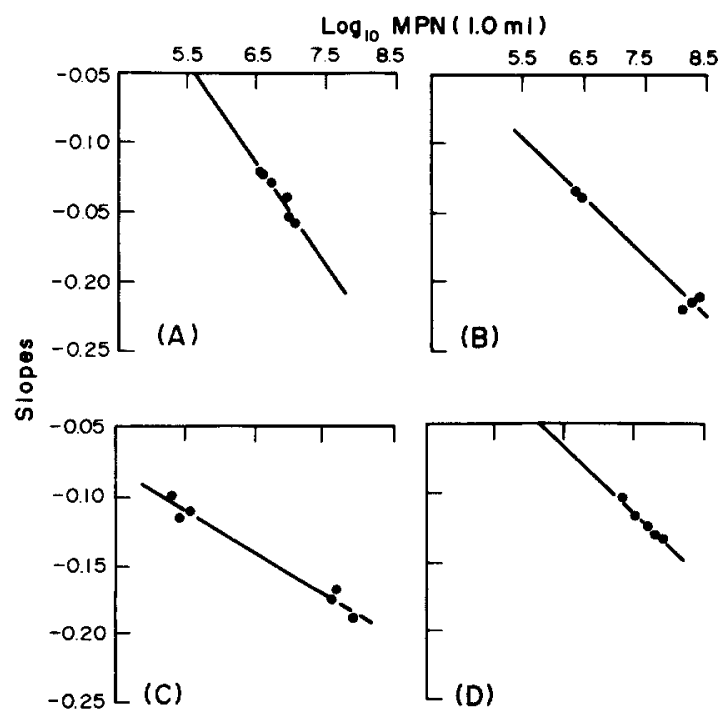

Fig. 3. Linear regression curves of significantly correlated infective initial titers and rates of decline at $26^{\circ} \mathrm{C}$ measured by CPE. (A) Rotavirus-distilled; (B) reovirus-distilled; (C) rotavirus-wastewater; (D) reovirus-wastewater.
Table 2. Average times for loss of $90 \%$ of virus activity

\begin{tabular}{lrr}
\hline \multicolumn{1}{c}{ Regime } & \multicolumn{2}{c}{ T $_{90}$ (days) } \\
& & $26^{\circ} \mathrm{C}$ \\
\hline Rotavirus & 185 & \\
Distilled water, IFA & 73 & 8.4 \\
Distilled water, CPE & 236 & 7.6 \\
Sewage, IFA & 84 & 7.8 \\
Sewage, CPE & 154 & \\
Reovirus & 130 & 6.6 \\
Distilled water, IFA & 630 & 6.8 \\
Distilled water, CPE & 262 & 13.3 \\
Sewage, IFA & & \\
Sewage, CPE &
\end{tabular}

sample collections produced the following ranges: $\mathrm{pH}$ 6.0-7.5; temperature $10-21^{\circ} \mathrm{C}$; turbidity $16-50 \mathrm{JTU}$ : BOD $120-156 \mathrm{mg} \mathrm{l}^{-1}$; suspended solids $144-172 \mathrm{mg}$ $1^{-1}$; volatile suspended solids $112-144 \mathrm{mg} \mathrm{l}^{-1}$; total alkalinity $245-272 \mathrm{mg} \mathrm{l}^{-1}$; organic nitrogen 9.1-11.2 $\mathrm{mg}^{-1}$; and ammonia nitrogen $14.7-19.8 \mathrm{mg} \mathrm{l}^{-1}$. The flow was 16.5-20.7 MGD. Grab sample wastewater pH's before virus inoculation measured $6.0-6.5$, temperature $13-21^{\circ} \mathrm{C}$ and turbidity $75-135$ NTU. Autoclaved double distilled water pH's were approx. 6.0 before addition of the viruses. After 1 month of incubation at $26^{\circ} \mathrm{C}$ and more than a year at $8^{\circ} \mathrm{C}$, wastewater pH's measured between 7.4 and 7.7 and distilled water from 6.3 to 7.2 .

\section{Significance of variables}

The bar graphs of Fig. 4 illustrate the averaged rates of decline for the various combinations of tem-
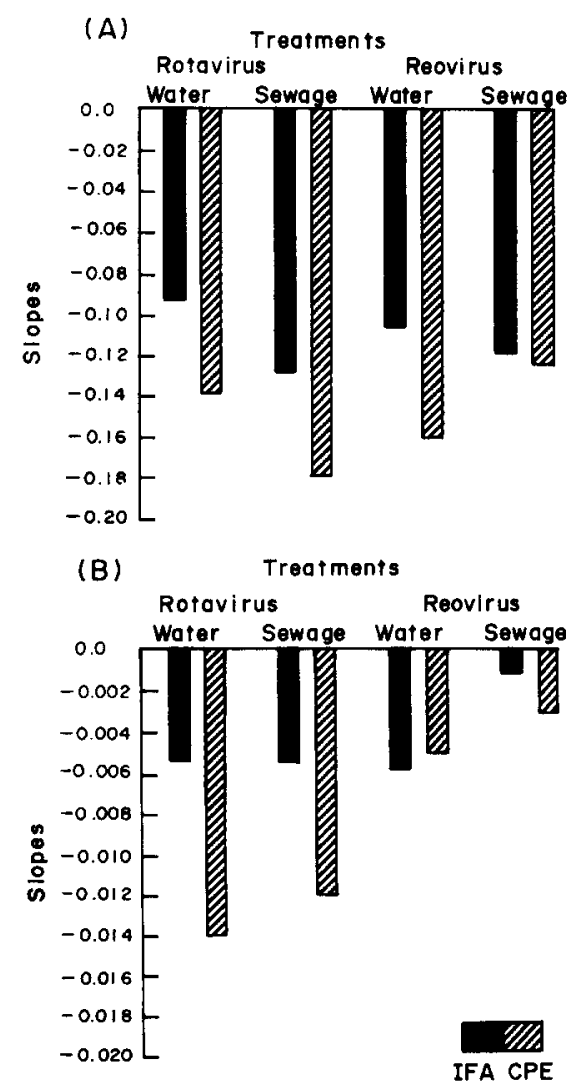

Fig. 4. Comparison of averaged rates of decline for viruses and water samples incubated at (A) $26^{\circ} \mathrm{C} ;$ (B) $8^{\circ} \mathrm{C}$. 
perature and medium. The following patterns may be observed: IFA rates of decline were usually slower than infectivity (CPE) rates; rates of virus decline at $8^{\circ} \mathrm{C}$ were $10-100$ times slower than at $26^{\circ} \mathrm{C}$; reovirus survived longer in sewage than did rotavirus. Analysis of variance performed on the adjusted and averaged rates of virus decline for the variables: virus, temperature, medium, assay and trial indicated that only temperature was significant.

\section{DISCUSSION}

Rotavirus and reovirus were found to survive more than 30 days at $26^{\circ} \mathrm{C}$ and longer than 1 year at $8^{\circ} \mathrm{C}$. Other enteric viruses have also withstood long periods of time in different types of waters (Mahnel et al., 1977; Rhodes et al., 1950; Berg, 1976). Toxic effects from detergents or other chemicals in the raw sewage samples used for survival studies apparently were present in insignificant amounts and did not have serious adverse effects on these viruses (Ward $\&$ Ashey, 1980). The present study suggests that, under conditions in which these viruses are protected from light, mixing, other organisms and toxic substances, their long-term survival in a temperate climate would be possible. This increases the opportunity for transmission of these viruses by the water route.

Results from the present study required 7-13 days for a loss of $1 \log$, as opposed to 3 to greater than 14 days for a loss of 3 logs reported by Hurst \& Gerba (1980). These differences may be explained by variations in experimental conditions. The previously published paper reported the use of polluted and nonpolluted fresh and estuarine waters not freed of microorganisms nor protected from exposure to light, and from which aliquotes were held in a frozen state before assaying. In addition, initial titers of their plaque purified model, simian rotavirus, were $2 \times 10^{4}$ plaques $\mathrm{ml}^{-1}$ as opposed to $1 \times 10^{6}-1 \times 10^{8} \log _{10}$ MPN $(1.0 \mathrm{ml})$ used in this study. A more rapid loss of infectivity would be expected in the presence of microorganisms, light (Cubbage et al., 1979) and freezing. In addition, plaquing may be considered less sensitive than the CPE assay (Schmidt et al., 1978). It is possible the calf isolate may have the potential of yielding higher titers in embryonic BEK cells than the simian isolate has in the adult derived cell lines of MA104 or LLC-MK 2 cells. On the other hand, arguments for more rapid rates of decline from the current study evolve from the use of a 5 day incubation period for CPE as opposed to the 2 week period used for incubation of plaque plates. In addition, since larger initial titers were found to decline at more rapid rates, as shown in Table 1, and were at least two logs above those of the previous study, they could also be a contributing factor.

The increased rates of decline for groups with the highest initial titers, larger $F$-statistics and positive correlation of initial titers with rates of decline as seen in results, all indicate that differences in initial titers do influence the significance of variables being tested. During the processes of averaging and adjusting, individual data variations were reduced sufficiently so that none of the variables were significant except temperature.

It is not known why significant correlations are found between initial titers and their rates of decline. One hypothesis offered in explanation is that if increased proportions of defective virus particles with shortened survival potential were present in those samples with the highest titers, greater interference with virus-cell interactions would lead to more rapid die-offs for these samples.

Akin (1971) has suggested that viruses in higher concentrations have greater tendency to aggregate. In this study, although the data are not presented, evidence of clumping was not seen when samples were monitored by electron microscopic examination. The majority of viruses viewed were single particles and only a few clusters of 2 and 3 were found.

Floyd \& Sharp (1977) reported that reovirus inoculated in water and stored for two weeks at 4 and $6{ }^{\circ} \mathrm{C}$ lost its property of aggregation, and, when diluted 100 -fold in water, as was done in the present study, it did not aggregate. The addition of trypsin to a small aliquot of rotavirus inoculated distilled and wastewaters before assaying, was intended to help break up clumps as well as to increase the titer.

There are several possible explanations for the slower rates of virus decline as measured by IFA. The IFA assay has the potential of detecting not only viable forms of viruses, but also defective and degraded forms which might adhere to cell surfaces or invade cells, but not be capable of multiplication; thus it may provide higher titers than those obtained from $C P E$, which indicated the presence of only those virions capable of destroying cells. Since identification by CPE required a change in cell structure visible by microscopic examination, a greater number of virus particles were required to produce visible cellular damage than were needed for identification by IFA, for which only one positive cell on a slide was necessary to indicate the presence of virus.

In wastewater, rates of virus decline were greater for rotavirus than for reovirus, and loss of infectivity for rotavirus at $8^{\circ} \mathrm{C}$ in distilled water was greater than that for reovirus. The prolonged survival of reovirus in wastewaters as compared to rotavirus may indicate a possible difference in the degree of attraction for, or ability to adhere to, particulates (Farrah et al., 1978; Goyal \& Gerba, 1979). Whether pasteurization may have altered the character of particulates toward a more favorable environment for virus survival is not known.

Ward \& Ashley (1980) reported that some positively and negatively charged compounds found in wastewater-sludge inactivated rotavirus, but not reovirus. The differences in survival times and loss in infectivity rates between rotavirus and reovirus in wastewater at 8 and $26^{\circ} \mathrm{C}$, and in distilled water at 
$8^{\circ} \mathrm{C}$, could be due to molecular variations between the two viruses. These viruses have their own sets of chemically different proteins, each with unique structural shape and different viral genome (Wyatt et al., 1978).

Since rotavirus titers dropped faster in wastewaters than did reovirus titers, it would appear that rotavirus did not benefit from protective effects of adsorption to particulates or other substances found in wastewater to the same extent as did reovirus. It is also possible that the elevated temperature of $26^{\circ} \mathrm{C}$ initiated chemical reactions not active at $8^{\circ} \mathrm{C}$, which had the effect of decreasing rotavirus titers at a more rapid rate than those of reovirus.

Acknowledgements-This paper was taken in part from a dissertation submitted by Audrey E. McDaniels in partial fulfillment of the requirements for the Ph.D. degree at The University of Michigan, Ann Arbor and supported in part by a grant from the U.S. Department of the Interior, OWRT Project No. B-054-MICH, through the Institute for Water Research of Michigan State University.

\section{REFERENCES}

Akin E. W. (1971) A study of the fate of selected enteric viruses in marine waters. Dissertation, University of Michigan, Ann Arbor, MI.

Berg G. (1976) Microbiology-detection, occurrence, and removal of viruses. J. Wat. Pollut. Control. Fed. 48, $1410-1416$.

Bryden A. S., Davies H. A., Thouless M. E. \& Flewett T. H. (1977) Diagnosis of rotavirus infection by cell culture. $J$. Med. Microbiol. 10, 121-125.

Chang S. L., Berg G., Busch K. A., Stevenson R. E., Clark N. A. \& Kabler P. W. (1958) Application of the "most probable number" method for estimating concentrations of animal viruses by the tissue culture technique. Virology 6, 27-42.

Clark S. M., Baranette B. B. \& Spendlove R. S. (1979) Production of high-titer bovine rotavirus with trypsin. $J$. clin. Microbiol. 9, 413-417.

Cubbage C. P., Gannon J. J., Cochran K. W. \& Williams G. W. (1979) Loss of infectivity of poliovirus 1 in river water under simulated field conditions. Water Res. 13, 1091-1099.

Dahling D. R. \& Safferman R. S. (1979) Survival of enteric viruses under natural conditions in a subarctic river. Appl. envir. Microbiol. 38, 1103-1110.

Dixon W. J. (1977) BMD Biomedical Computer Programs, 3rd Edition. University of California Press, Los Angeles.

Draper N. R. \& Smith H. (1966) Examining the regression equation. Applied Regression Analysis, p. 25. Wiley, New York.

Farrah S. R., Goyal S. M., Gerba C. P., Conklin R. H., Wallis E., Melnick J. L. \& Dupont H. L. (1978) A simple method for concentration of enteroviruses and rotaviruses from cell culture harvests. Intervirology. 9, 56-59.

Floyd R. \& Sharp D. G. (1977) Aggregation of poliovirus and reovirus by dilution in water. Appl. envir. Microbiol. 33, $159-167$.

Gerba C. P. (1980) Personal communication, Department of Virology and Epidemiology, Baylor College of Medicine, Houston, TX.
Goyal S. M. \& Gerba C. P. (1979) Comparative adsorption of human enteroviruses, simian rotavirus and selected bacteriophages to soils. Appl. envir. Microbiol. 38, 241247.

Hurst C. J. \& Gerba C. P. (1980) Stability of simian rotavirus in fresh and estuarine water. Appl. envir. Microbiol. $39,1-5$.

Kapikian A. Z., Yolken R. H., Greenberg H. B., Wyatt R. G., Kalica A. R., Chanock R. M. \& Kim W. W. (1979) Gastroenteritis viruses. Diagnostic Procedures for Viral, Rickettsial and Chlamydial Infections (Edited by Lennette E. H. \& Schmidt N. J.), 5th Edition, pp. 927-995. American Public Health Association, Washington, DC.

Mahnel H., Ottis K. \& Herlyn M. (1977) Stability in drinking and surface water of nine virus species from different genera. Zentbl. Bakt. Parasitkde 164, 64-84.

McDaniels A. E. P. (1981) Rotavirus and reovirus stability in freshwater and a virus survey of a wastewater treatment facility. Doctoral Dissertation, Michigan.

Melnick J. L. \& Rennick V. (1980) Infectivity titers of enterovirus as found in human stools. J. med. Virol. 5, 205-220.

Neter J. \& Wasserman W. (1974) Inferences in regression analysis (pp. 53-96). Topics in regression analysis (pp. 140-175). In Applied Linear Statistical Models. Richard D. Irwin, Homeweed, IL.

Ostle B. (1954) Correlation methods. In Statistics in Research, pp. 180-181. The Iowa State College Press, Ames, IA.

Rhodes A. J., Clark E. M., Knowles D. S., Goodfellow A. M. \& Donoheu W. L. (1950) Prolonged survival of human poliomyelitis virus in experimentally infected river water. Can. J. publ. Hlth 41, 146-149.

Riggs J. L. (1979) Immunofluorescent staining. Diagnostic Procedures for Viral Rickettsial and Chlamydial Infections (Edited by Lennette E. H. \& Schmidt N. J.), 5th Edition, pp. 141-170. American Public Health Association, Washington, DC.

Rowe R., Todd R. \& Waide J. (1977) Microtechnique for most-probable-number analyses. Appl. envir. Microbiol. 33, $675-680$.

Schmidt N. J. (1979) Cell culture techniques. Diagnostic Procedures for Viral Rickettsial and Chlamydial Infections (Edited by Lennette E. H. \& Schmidt N. J.), Sth Edition, pp. 65-139. American Public Health Association, Inc., Washington, D.C.

Schmidt N. J., Ho H. H., Riggs J. L. \& Lennette E. H. (1978) Comparative sensitivity of various cell culture systems for isolation of viruses from wastewater and fecal samples. Appl. envir. Microbiol. 36, 480-486.

Sekla K., Stackiw W., Kay C. \& Van Buckenhout L. (1980) Enteric viruses in renovated water in Manitoba. Can. $J$. Microbiol. 26, 518-523.

Steinhoff M. C. (1980) Rotavirus: the first five years. $J$. Pediat. 96, 611-622.

Ward R. L. and Ashley C. S. (1980) Effects of wastewater sludge and its detergents on the stability of rotavirus. Appl. envir. Microbiol. 39, 1154-1158.

World Health Organization (1979) Human viruses in water, wastewater and soil. Technical WHO Report Series 639

Wyatt R. G., Kalica A. R., Mebus C. A., Kim H. W., London W. T., Chanock R. M. and Kapikian A. Z. (1978) Reovirus-like agents (rotaviruses) associated with diarrheal illness in animals and man. In Perspectives in Virology (Edited by Pollard M.). Raven Press, New York. 